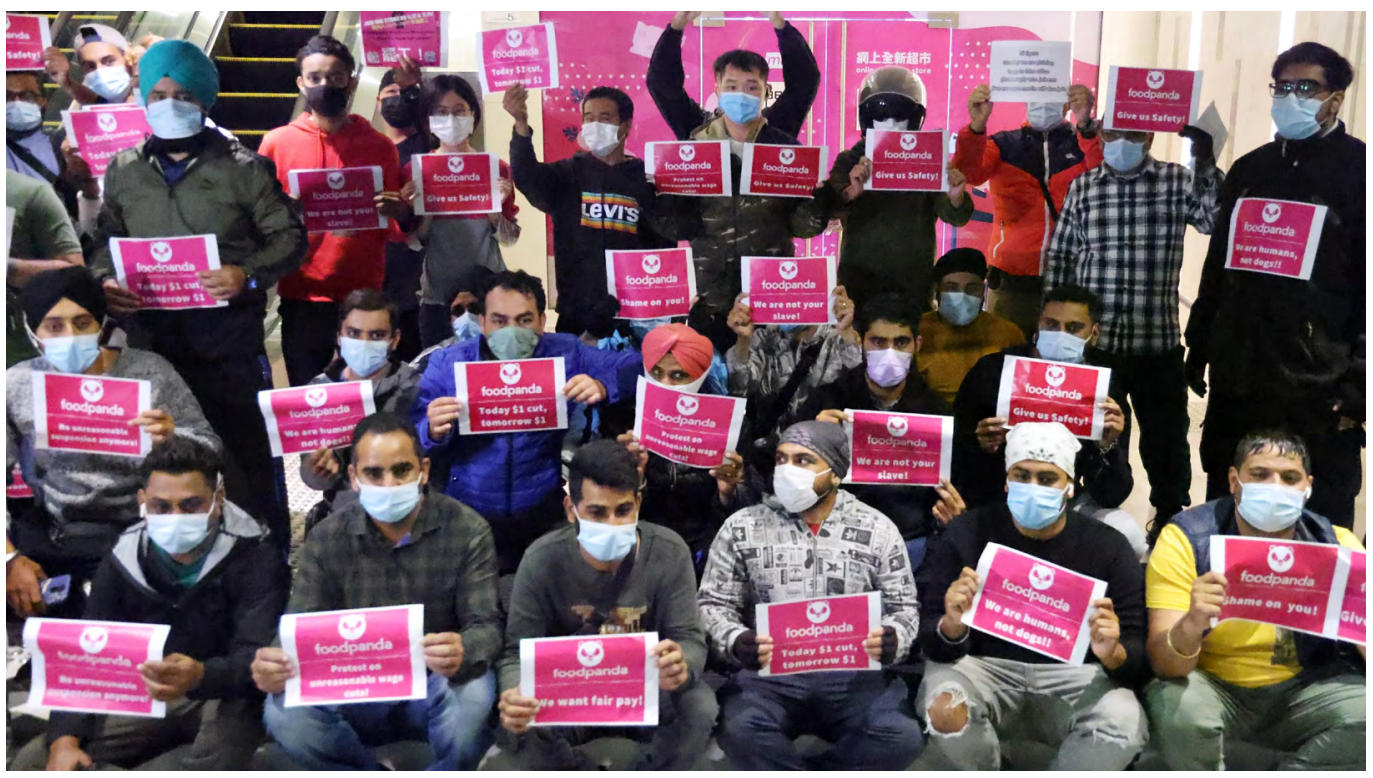

Foodpanda workers on strike in Kowloon Bay. PC May Tse, South China Morning Post.

\section{A New Chapter for Hong Kong's Labour Movement?}

\section{Kevin LIN}

The optimism triggered by the growth of a more powerful independent labour movement in Hong Kong in 2019 has now been replaced with pessimism about the very survival of such a movement. If one chapter has arguably been closed, what will the next chapter look like for Hong Kong's labour movement? This essay looks at three episodes: the demise of the leading independent trade union in the city, the struggles of the new unions that have emerged in the past few years, and the recent strikes by delivery workers. Each of these episodes reveals something about the moment we are in and, together, they provide some clues as to what lies ahead. he labour movement in Hong Kong is something of an enigma. Hong Kong is the only territory under the sovereignty of the People's Republic of China that allows its workers to organise and freely join independent trade unions, and they have done so in the hundreds of thousands. Trade union registration is not particularly difficult, and political interference has been minimal until recently. Strike action, for the most part, is legal and protected. Workers have taken advantage of this political space to build an independent trade union movement unaligned with the government. 
Yet, despite such politically favourable conditions, the Hong Kong independent labour movement-as represented by the now defunct Hong Kong Confederation of Trade Unions (HKCTU, 香 港职工会联盟), which used to represent more than 160,000 members in 61 affiliated unions-has not managed to wield significant economic or political power. Labour remains marginalised. This fact is perhaps not in itself remarkable because of the long-term decline of trade unionism across much of the world under neoliberalism. But it poses interesting questions when compared with the dynamism displayed by the labour movement in mainland China, where collective action by workers has been the norm for much of the past two decades despite the obvious political constraints (Hui 2019).

However, the events of the past two years have profoundly shaken the Hong Kong labour movement in complex and contradictory ways. First, the general strikes of 2019 and the wave of unionisation starting later that year and continuing into early 2020 suddenly imbued Hong Kong trade unions with a newly found relevance, raising hopes that organised labour would play a more central role in the city's politics to highlight problems of social and economic rights and not just political rights (Pringle 2021). Events took a drastic turn in mid-2020, especially after the enactment of the Hong Kong National Security Law (NSL), when several vocal trade unions became the targets of criticism, pressure, and open persecution. As many of the most vocal union leaders were arrested and are awaiting trial, this posed an existential crisis for the very survival of independent trade unionism in the city.

A general pessimism understandably prevails today. But it has also been counterbalanced by a belief among union organisers that workers' collective actions will continue even under these new, exacting circumstances. As Leo Tang, the former vice-chair of the HKCTU, wrote on the disbandment of the organisation:

We know that the relationships forged among workers will not be dissipated by today's decision [to disband the HKCTU] ... The struggles in every industry and workplace have proved that ' where there is oppression, there is resistance'. We believe that this will continue to be the case in the future. (Tang 2021)

Indeed, a strike by Foodpanda delivery workers in November 2021 seemed to justify, to a certain extent, such optimism, even though it remains an isolated incident for now. In this essay, I will argue that to gain a sense of what the next chapter of Hong Kong's labour movement may look like, it is important to consider three episodes to which I have already briefly alluded: the end of the HKCTU, the state of new unions, and the recent delivery workers' strike.

\section{The HKCTU and Independent Trade Unionism}

The dissolution of the HKCTU announced on 3 October 2021 closed a critical chapter in the development of an independent trade union movement in Hong Kong. Over the past 30 years, this movement, centred on the HKCTU, has stood explicitly against the complicity of the pro-establishment trade unions, taking pride in its workers' militancy and engagement in the city's political affairs. The HKCTU has been such a fixture in Hong Kong's social and political landscape that its decision to disband-although not unexpected after months of attacks and threats-sent shockwaves through the city and caused demoralisation. How should we evaluate the impact of its disappearance?

In political and economic terms, the HKCTU was very much a product of its time. Founded in July 1990, the confederation emerged from a period of independent labour organising and democratic opposition that started in the 1970s (Chiu 2011). Set explicitly in opposition to the then dominant pro-establishment Hong Kong Federation of Trade Unions (HKFTU, 香港工会联合会), the HKCTU led a revival of more militant tactics in the city's labour movement. And, because of its origin, it saw itself as not simply a labour union, but rather part of broader political and social movements in Hong Kong, with its leaders participating in elections and even forming the Labour Party 
(工党) to influence the political and legislative agendas-even though there were always tensions about whether the HKCTU should prioritise labour organising or political engagement.

The HKCTU was also an integral part of the global labour movement, not just through formal membership of the International Trade Union Confederation (ITUC) - one of the most influential global trade union federations-but also through its exchanges with and solidarity actions across Asia and beyond. For decades, the HKCTU could be counted on to extend solidarity and practical support to the labour movement in mainland China and elsewhere in the world.

From its inception, the HKCTU found itself operating in a largely post-industrial economy, as manufacturing production had already begun to relocate from Hong Kong to mainland China and elsewhere in Asia from the 1980s. The conditions for strong industrial and manufacturing unions that historically have formed the backbone of trade union movements in capitalist economies did not exist for the new unionists who came on the scene in the Hong Kong of the 1990s. The stronger worker organisations were instead white-collar, professional, and public-sector unions, such as the Hong Kong Professional Teachers' Union (PTU, 香 港教育专业人员协会), which also became a major government target in 2021 and also eventually decided to disband. Union activity and mobilisation at the workplace level did not always match the high profile of the HKCTU, with a discrepancy between the high-level political engagement of the confederation and the weakness of worker power at the grassroots level.

The HKCTU and its allies developed a tradition of social movement unionism in which the lack of workplace-based power was compensated by the mobilisation of social groups for solidarity action and public pressure. This approach was predicated on the ability of social actors to participate in solidarity action and gain broad public support, as well as the unique position of Hong Kong as a global city where businesses took care to avoid reputational damage both locally and internationally. Such social movement unionism relied on the activism of unions, civil society organisations, student groups, left-wing activists, and other concerned citizens joining together to amplify workers' messages. Yet it was also characterised as a 'double-edged sword' for workers' power, as it was argued that, while the mobilisation of social groups created societal power for workers, it could also become a substitute for workers' own militancy (Chan et al. 2019).

Be that as it may, the disbandment of the HKCTU has undoubtedly undermined this model of social movement unionism and is a serious loss for Hong Kong. Of course, the demise of the confederation does not necessarily spell the end for its affiliated unions. For instance, the Hotel Employees' Union issued a message about the dissolution of unions and other organisations:

\section{We might not be able to recover the affec- tions and bonds we once had, but we can organise again even if an organisation dies. Whether it's hotel work or other sectors, we anticipate working conditions becoming worse and worse... We can still band together in solidarity to raise our collective demands- just like before. (Hong Kong Hotel Employees' Union 2021)}

Nevertheless, the disappearance of the HKCTU means less support for its affiliates, especially the more precarious domestic workers' unions, and less capacity to coordinate organising and united actions. Combined with the closure of other powerful unions, such as the PTU, which cost the city's labour movement hundreds of thousands of unionised white-collar workers, the impact has been devastating.

However, as a product of its time, the HKCTU sometimes found itself out of place as events rapidly unfolded, especially when they took a radical turn. Although it joined the call for general strikes at the height of the 2019 protests, the HKCTU on its own did not have the power to mobilise; rather, it required the disruptive power of a few determined unions and individual activists (Au 2020). There was also an uneasy relationship between the HKCTU as an institution and those on the street and the front lines of the anti-Extradition Law Amendment Bill movement. Before the unionisation wave that took place in late 2019, few 
of those on the street were likely to be members of a trade union, either because they were students or because they worked in non-unionised sectors, and thus they were largely unfamiliar with the city's trade union movement. Moreover, as the HKCTU was enmeshed in the pan-democracy opposition camp as one of its more radical wings, many in the new generation of activists saw it as complicit in the pan-democracy camp's failure to stage effective opposition. So, while some of the new unions that emerged in 2019 developed close relationships with the HKCTU, many others chose not to affiliate with it.

\section{New Unions in Crisis}

The wave of unionisation that took place in late 2019 temporarily ignited a great deal of hope that more organised working-class power would emerge in Hong Kong. More than 450 new unions were established in less than a year, with hundreds of thousands of workers signing up for membership. One of the most important new unions was the healthcare workers' Hospital Authority Employees Alliance (HAEA, 医管局员工阵线), which played a key role in early efforts to combat the Covid-19 outbreak in the city (Chan 2020). But workers were also organising in new industries, establishing, for instance, unions for accountants and those in the financial sector. Sectors with many young, and often highly informal, workers witnessed a flourishing of new unions. The goal at the time was more explicitly political, with these organisations seen as an extension of the political movement and as a voting bloc to secure elected positions in the legislature. This development did generate increased interest in focusing on growing power through worker organisations, if not necessarily mobilising around labour rights per se.

However, facing the same challenges as unions everywhere, these new trade unions have been struggling to stay afloat under the increased political pressure of recent months. While in 2019 they easily signed up new members, throughout 2020 and 2021, many struggled to grow their membership and some spent considerable energy just to retain existing members (Tsai and Chan 2021). In the final months of 2021, some of these unions announced their closure on social media, which rarely merited any mention in the mainstream press, and it is unclear how many are still functioning. Political pressure has contributed to the crisis in these organisations, but the biggest problem is these groups have not been given the time to build up membership and capacity. Even though their predicament may deter others thinking about unionising, their closure should not be seen as an indicator of the viability of trade unions. It would be too hasty to dismiss their potential.

\section{Labour Activism in the Post- Union Era}

Against this backdrop, the Foodpanda delivery workers' strike of November 2021 came as a pleasant surprise. The mobilisation was triggered by gradually increasing cuts to workers' delivery fees. In the weeks leading up to the strike, delivery workers used their informal networks and communicated via WhatsApp groups to voice their indignation. Over days of discussions, their disgruntlement escalated into a plan to demonstrate outside PandaMart stores and refuse to take orders from them over the weekend. Hundreds showed up at the demonstrations, and it is estimated several thousand took part in the strike. They crystallised their demands around restoring their delivery fees, as well as changes to the Foodpanda app's algorithm to improve their working conditions. This action successfully forced the company to the table and, after two rounds of negotiation, the company agreed to most of the workers' demands.

As the now defunct Stand News (2021) put it, the strike represented a form of labour activism in the post-union era. While not particularly large in scale, the strike took on particular significance as a test of the limits of activism under the changed political circumstances. As open protests have become risky, the delivery workers' strike gained attention not only for its successful mobilisation, but also as a 
gauge of how the police would react; as it turned out, they did try to disperse public demonstrations but otherwise largely left the workers alone.

In many ways, there are more continuities than discontinuities between the conditions and actions of delivery workers now and those before the recent dissolution of trade unions. The Foodpanda delivery workers' strike was only the latest of several successful and failed mobilisations over the past several years by delivery workers at the two main food delivery platforms in Hong Kong, Foodpanda and Deliveroo. These episodes share similar conditions and grievances. Key issues centre on the reduction of delivery fees that over time significantly cut workers' incomes, as well as the suffocating algorithmic control over the work process and time management. South Asian immigrants have played an oversized, active role in the strike actions despite most of the workforce being ethnically Chinese Hong Kong residents (Stand News 2021).

Delivery workers in Hong Kong have never belonged to a trade union or any other form of worker organisation. While previously HKCTU organisers and affiliated unions have supported the organising efforts of delivery workers, there has never been any formal relationship between them. The strike actions have been self-organised from within, and the delivery workers themselves have led the strikes (Hui and Ho 2021). Based on discussions in November and December 2021, leading delivery worker organisers, as well as delivery workers more broadly, are unwilling to form their own union, believing it would be a burden and constraint on their activities. This conforms with a global pattern that sees newly emerged platform workers largely eschew traditional trade unions. Globally, some have organised their own unions, collectives, or other associations, but they maintain only tenuous links with more established trade unions. Without a union's organisational structure, any mobilisation is most likely ad hoc, and gains made through the action are arguably more difficult to secure and sustain.

There are some notable differences between the latest strike and earlier ones. The latest mobilisation deliberately maintained a non-political stance, focusing squarely on issues related to pay and conditions. Although no previous action turned political, some did incorporate ideas like the 'five demands' but used them to refer to their own labour demands. And while the absence of the HKCTU did not necessarily directly affect the labour organising itself, it did deprive the activism of the external solidarity and public pressure that were the hallmarks of community-based social movement unionism. With very little external mobilisation, the Foodpanda workers' strike did not gain any significant public support and depended almost exclusively on the workers' own disruptive power.

In a sense, the role of trade unionism and the labour movement cannot be reduced to just the level of political pressure in Hong Kong; it should be understood also in the context of the decline in trade unionism in many parts of the world. Self-organised direct action by non-unionised workers, excluded or otherwise unrepresented by traditional unions, is often the main form of worker resistance today.

\section{The Next Chapter}

I write as an observer, and therefore I am not in a position to shape the movement. If recent events are any indication, the horizon for Hong Kong's labour movement is likely to shrink to mostly economic demands. Political activism by trade unions could be deterred for a long time to come. In many ways, this situation is familiar to observers of the labour movement in mainland China. Economic demands are usually accepted as legitimate there, as long as workers do not escalate their collective action into open street protests or demonstrations that threaten social stability outside the factory gates. While independent trade unions have always been out of the question on the mainland, labour nongovernmental organisations (NGOs) were tolerated until recently, if they provided only social services and legal counsel and did not take a leading role in workers' actions. There were immediate repercussions if they crossed the line (Franceschini and 
Lin 2019) and, after successive waves of repression between 2015 and 2019, even that limited space has now largely vanished.

In Hong Kong, trade unions still have greater space for organising than on the mainland. In other ways, however, it may be harder for the Hong Kong labour movement to adapt in this new era. Hong Kong's independent trade unions used to operate under a set of rules that largely no longer apply, whereas their mainland counterparts have been working in a semi-legal environment since the very beginning and therefore have long been accustomed to such rules (or lack thereof)-even though it must be reiterated that, despite this familiarity, mainland Chinese labour NGOs are also struggling in the current political climate.

What, if anything, can be learned from how the Chinese Party-State has responded to growing worker activism in the mainland that could be relevant to the Hong Kong labour movement? Organisations and networks are to be shattered, and individuals will be kept under close watch. But the state strategy has also at times been more nuanced. A recent study shows the Chinese authorities have reacted to worker mobilisations not only by increasing repression, but also with increased responsiveness-for instance, by pushing for outcomes from mediation and arbitration more favourable to workers and other means to accommodate workers' interests and prevent escalation (Elfstrom 2021). The two contexts are radically different, so whether the exact same strategy will be followed in Hong Kong remains to be seen.

However, trade union weakness is not just a product of repression. The Hong Kong labour movement had its own shortcomings well before 2019. The changing structures of the economy and employment relations are critical factors shaping the labour movement, in the city as anywhere else. The new trade unions that emerged in Hong Kong in the past couple of years saw the need to unionise young workers in service and informal sectors that are notoriously difficult to organise, pointing to the urgency and the possibilities of organising such an often precarious and marginalised workforce. Furthermore, the Foodpanda strike also revealed the racialised segmentation of the Hong Kong working class, while at the same time displaying the activism of workers of South Asian origins. By highlighting these dynamics, it demonstrated the necessity of overcoming racial divisions and building unity among workers of different ethnicities and national origins.

With a tough new chapter ahead, readjusting to the new reality requires rethinking not only strategies and tactics, but also organisational forms and approaches. A new generation of labour organisers may emerge. How they and the movement as a whole respond to the new conditions will need to consider not only politics but also changes in the broader economic and employment landscape. In this sense, while trade unions as we traditionally understand them are important, exploring new ways of labour organising is both a necessity and an opportunity. 
This text is taken from Made in China Journal: Volume 6, Issue 3, 2021, edited by Ivan Franceschini, Nicholas Loubere and Shui-yin Sharon Yam, published 2022 by ANU Press, The Australian National University, Canberra, Australia.

doi.org/10.22459/MIC.06.03.2021.09 